https://doi.org/10.19195/0080-3626.63.3

VLASTA OKOLIČÁNYOVÁ

KATARÍNA DEVEROVÁ

GABRIELA ŽIBRITOVÁ

\title{
ZARĘCZYNY FRANTIŠKA NÁDAŠDYEGO I ELŻBIETY BATORY JAKO WYDARZENIE SPOŁECZNE I FAKT LITERACKI XVI WIEKU*
}

Sylwetki Františka Nádašdyego i Elżbiety Batory. Autor Epithalamion conivgii... Benedikt Ilošvai. Epitalamium jako rodzaj utworu okolicznościowego. Treść Epithalamium coniungii... i jego wyposażenie artystyczne.

SŁOWA KLUCZOWE: František Nádašdy, Elżbieta Batory, Benedikt Ilošvai, drukarstwo krakowskie XVI wieku, epitalamium

Duo lumina maxima gentis Pannonicae - felix ille dies! (Dwie największe ozdoby narodów Panonii — jeden szczęśliwy dzień!) Epithalamion coniugii, 1571

\section{WPROWADZENIE}

W 1571 roku w Krakowie w oficynie Mateusza Siebeneichera został wydany skromny objętościowo druczek okolicznościowy autorstwa Benedikta Ilošvaia (Benedictus Ilosvanus), pod tytułem Epithalamion conivgii magnifici domini Francisci Nadasdi, comitis castri Ferrei, et generosae dominae Helizabeth magnifici domini Georgii de Bathor filiae. Honorabile coniugium immaculatum ${ }^{1}$. Poświęcony był zaręczynom magnata węgierskiego Františka Nádašdyego z przedstawi-

* Artykuł jest rozszerzoną o polską literaturę wersją artykułu, który ukazał się w czasopiśmie „Knižnica” 20, 2019, nr 1, s. 59-64.

${ }^{1}$ Cracoviae: In Officina Matthaei Siebeneycheri. Anno Do: M D LXXI. [= 1571]. 4․ A - C4, D2 [14 kart]. Egzemplarz tego druku znajduje się w Bibliotece Zakładu Narodowego im. Ossolińskich we Wrocławiu, sygn. XVI. Qu. 2637. Kopia cyfrowa zob. https://www.dbc.wroc.pl/dlibra/ publication/13397/edition/11910/content?ref=de [dostęp: 6.04.2019]. 
cielką innej możnowładczej rodziny węgierskiej, Elżbietą Batory (węg. Báthory Erzsébet, słow. Alžbeta Bátoriová), i to jej postać skłania do bliższego przyjrzenia się temu drukowi ${ }^{2}$. Gdy tylko bowiem przywołane bywa jej imię, natychmiast pojawiają się skojarzenia z kobietą, która mordowała, popełniała zbrodnie, nurzała się we krwi. Jej czyny opisują z nieustającym zapałem liczni autorzy w naukowych i popularnych tekstach ${ }^{3}$. Wymieniony druczek pozwala jednak spojrzeć na jej postać także w nieco innym kontekście. W chwili zaręczyn Elżbieta miała zaledwie 11 lat, jej zbrodnie miały dokonać się dopiero w przyszłości, a na razie jej imię stało się głośne w świecie w związku z zaplanowanym mariażem.

Dzieło Benedikta Ilošvaia wpisuje się w mentalność i styl życia ówczesnych elit społecznych, dla których uroczystości zaręczyn i zaślubin członków rodów zajmowały niezwykle ważne miejsce. Losy przedstawicieli warstw panujących i szlacheckich wyznaczały rytm życia państwa, wpływały na życie gospodarcze, społeczne i religijne. Kto z kim? — było pytaniem interesującym i ważnym $z$ wielu powodów; małżeństwa były fundamentem sojuszy politycznych i ekonomicznych, przyczyną wojen, narodzin i upadku mocarstw. Nikt nie przejmował się uczuciami 10-15-letnich dzieci, decydowali rodzice, a czasem dalsza rodzina, ich interesy, a często interesy jeszcze innych osób. Kiedy uzgodniono warunki, należało dokonać zaślubin i upamiętnić ten fakt zarówno dla współczesnych, jak i dla przyszłych pokoleń, a temu doskonale służyła forma drukowana. Dokumenty archiwalne - listy, dokumentacja gospodarcza - informują o trwających tygodniami spotkaniach, o liczbie zjedzonych wołów i ilości wypitego wina. Teksty drukowane przynosiły coś innego - w formie literackiej stawały się okazją do ukazania znaczenia rodzin pana młodego i panny młodej, dawały wyraz nadziejom, jakie nowy związek małżeński miał przynieść dla ich rodzin i dla kraju. Wbrew temu, że w większości niezbyt szanowano uczucia młodej pary, nie brakowało w przeszłości także romantycznych związków i szczęśliwych małżeństw. Na końcu drogi każdego człowieka z kolei czekało to, co stawało się tematem kolejnej kategorii druków — kazań i mów pogrzebowych.

${ }^{2}$ Niniejszy artykuł jest rezultatem zbiorowego wysiłku trzech autorek. Pierwsza znalazła o odnośnym druku informację w bazie danych rejestrującej stare druki, druga miała sposobność zapoznać się z oryginałem w Bibliotece Zakładu Narodowego im. Ossolińskich we Wrocławiu i uzyskać informację o jego zdigitalizowanej wersji. Trzecia zaś udzieliła specjalistycznej pomocy w zrozumieniu jego łacińskiego tekstu i wpisaniu go w kontekst historyczny.

${ }^{3}$ Spośród licznych najnowszych opracowań na jej temat zob. m.in. R. McNally, Dracula Was a Woman. In Search of the Blood Countess of Transylvania, New York 1983; V. Penrose, The Bloody Countess. The Crimes of Elizabeth Bathory, London 1996; T. Thorne, Countess Dracula. The Life and Times of Elisabeth Bathory, the Blood Countess, London 1997; P. Dvořák, Krvavá grófka. Alžbeta Bátoryová, fakty a výmysly, Budmerice 1999; M. Farin, Heroine des Grauens. Elisabeth Báthory, München 2003.

ROCZNIKI BIBLIOTECZNE

ROK LXIII, 2019

(C) for this edition by CNS 


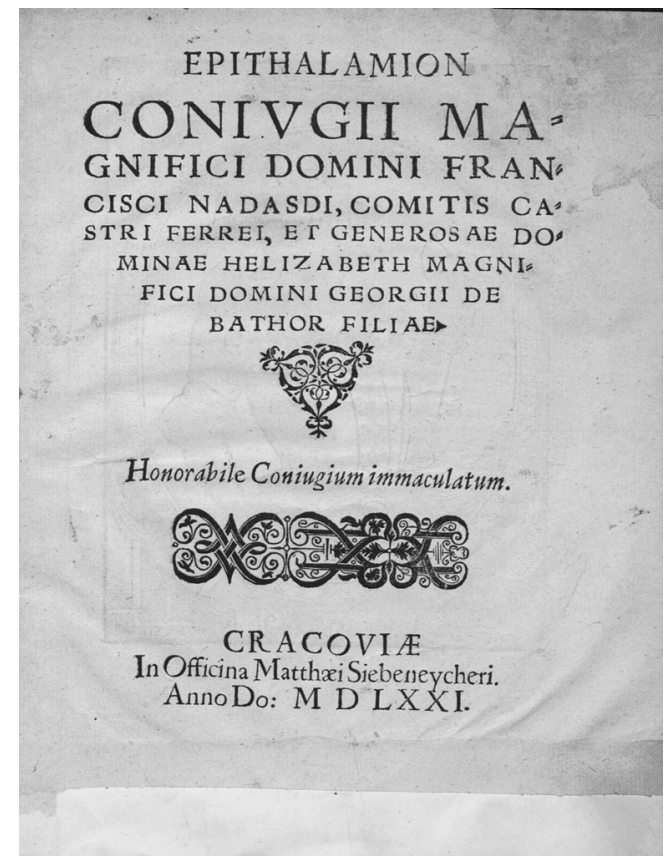

Il. 1. Karta tytułowa Epithalamion coniugii..., Cracoviae 1571

Źródło: Biblioteka ZNiO, sygn. XVI. Qu. 2637 (również wszystkie dalsze drzeworyty).

\section{SYLWETKI NARZECZONYCH}

František Nádašdy (Sárvár, Węgry, 6 października 1555-4 kwietnia 1604 roku), stołeczny dygnitarz, sławę zyskał — podobnie jak jego ojciec — w wojnach przeciw Turkom. Należał do największych węgierskich posiadaczy ziemskich. Jego rodzicami byli Tomáš Nádašdy i Uršula Kanižaiova. Na początku żołnierskiej kariery służył najpierw jako kapitan w wojskach naddunajskich. W walkach z Turkami zyskał przezwisko „Czarny Bej” i zasłynął z okrucieństwa wobec nieprzyjaciół. Brał udział w wielu zwycięskich bitwach z Turkami. Później pełnił funkcję żupana i królewskiego koniuszego. Na jego polecenie nadworny kaznodzieja Štefan Mad’ari (István Magyari) spisał jego doświadczenia wojenne - opowiedział się tam za ochroną obywateli i przedstawił swoje opinie o jakości sztuki wojennej. Nádašdy był wielkim protektorem ewangelików ${ }^{4}$. Już za życia František Nádašdy był adresatem wielu dedykowanych mu druków, licznych zwłaszcza w roku jego śmierci - $1604^{5}$.

${ }^{4}$ Biografický lexikón Slovenska, T. 6, Martin 2017, s. 648.

5 W dawnej siedzibie rodu, w mieście Sárvár, istnieje muzeum poświęcone jego wnukowi o tym samym imieniu - szlachcicowi, bibliofilowi, straconemu za udział w spisku przeciw cesarzowi, na którego czele stał František Vešeléni (Wesselényi, 1605-1667). 
Elżbieta Bátory, znana też jako Pani na Čachticach lub Krwawa Hrabina, pochodziła ze szlacheckiego rodu i miała znakomitych przodków: jej ojcem był żupan Juraj Bátori, matką Anna Bátori - córka wojewody siedmiogrodzkiego Štefana Bátori z innej gałęzi rodu, a zarazem siostra króla Polski — Stefana Batorego. Elżbieta urodziła się 7 sierpnia 1560 roku na Węgrzech, w mieście Nyírbátor, a zmarła 21 sierpnia 1614, także na Węgrzech, uwięziona dożywotnio na zamku w Čachticach. Po ślubie, który miał miejsce w 1575 roku we Vranovie nad Toplou, zamieszkała, jak było to w zwyczaju, w posiadłościach małżonka - Františka Nádašdyego - w Sárvár. Główną siedzibą nowożeńców po ślubie były dobra Keresztúr, ale Elżbieta zatrzymywała się również w Čachticach, w zamku koło Pieštan, w pałacach w Bratysławie i Wiedniu 6 .

\section{AUTOR EPITALAMIUM}

Benedikt Ilošvai (łac. Benedictus Ilosvanus, węg. Benedek Ilosvai) nosił nazwisko pochodzące od nazwy miasta zwanego po węgiersku Ilosva, po ukraińsku Iršava, położonego 40 kilometrów od Mukaczewa (Ruś Zakarpacka) - miasta, które do 1918 roku należało do Królestwa Węgierskiego, a obecnie do Ukrainy. Ilošvai studiował od 7 lipca 1558 roku na protestanckim uniwersytecie w Wittenberdze, gdzie wpisany został do metryki uniwersyteckiej jako Benedictus Ilosvanus ${ }^{7}$. Był tam członkiem społeczności studentów węgierskich (nacji węgierskiej), dla której w niedziele w swoim domu teksty biblijne wykładał po łacinie pedagog i teolog Filip Melanchton, nie wszyscy bowiem węgierscy studenci od początku znali niemiecki na tyle, aby rozumieć wykłady w tym języku. Wiadomo też, że przez pewien czas (około 1560 roku) przebywał w szwajcarskiej Genewie, będącej podobnie jak Wittenberga ważnym ośrodkiem protestantyzmu, gdzie słuchał kazań teologów Reformacji - Jana Kalwina i Teodora Bezy. Po powrocie na Węgry w 1560 roku został wyświęcony na seniora pięciu wolnych miast królewskich w węgierskiej gminie Tállya ${ }^{8}$. Od 1562 roku Ilošvai był pierwszym rektorem siedmiogrodzkiego uniwersytetu reformowanego w mieście Nagy Enyede (dziś: Aiud nad rzeką Muraš, Rumunia). W roku następnym - 20 maja 1563 - Benedikt Ilošvai ożenił się z Julianą Kokavian, córką Bricciusa Kokaviana9.

${ }^{6}$ Biografický lexikón Slovenska, T. 1, Martin 2002, s. 269-270.

7 L. Bartholomaeides, Memoriae Vngarorum qui in alma condam Vniversitate Vitebergensi studia confirmarunt, Pesthini 1817, s. 35; A. Szabó, Coetus Ungaricus a Wittebergi Magyar diáktarsaság 1555-1613, „Reformatus Szemle” 110, 2017, nr 5, s. 524-525.

8 Ecclesia Taliensis — kościół w mieście Tallya, leżącym w powiecie (węg. okres) Szerencz, Boršodsko-abovsko-zemplínska župa.

9 Z. Csepregi, Evangélikus lelkések Magyarországon (ELEM), s. 749, https://medit.lutheran. hu/site/konyv/2958 [dostęp: 5.06.2018]. To jedyne źródło, które świadczy, że Benedikt Ilošvai był żonaty (był żonatym duchownym). 
Udział Ilošvaia w synodzie w Koszycach 26 stycznia 1566 roku potwierdza jego zachowany autograf ${ }^{10}$. W 1571 roku, a więc w czasie, gdy pisał gratulacyjny wiersz z okazji zaręczyn Františka Nádašdyego i Elżbiety Bátory, Ilošvai (jak informuje jedyny druk) był kaznodzieją w mieście Vranov nad Toplou we wschodniej Słowacji. U schyłku swego życia, w latach 1573-1586, był dziekanem w Alba Julia. Nazwisko Ilošvaia jako autora wierszy lub adresata dedykacji pojawia się w publikacjach autorów wydawanych w Niemczech i Szwajcarii.

PRZYCZYNA OPUBLIKOWANIA EPITALAMIUM

Nie wiadomo, kto zlecił i sfinansował druk Epithalamion coniugii... - w dedykacji Benedikt Ilošvai swoje gratulacje skierował wyłącznie ku przodkom rodów Nádašdych i Batorych.

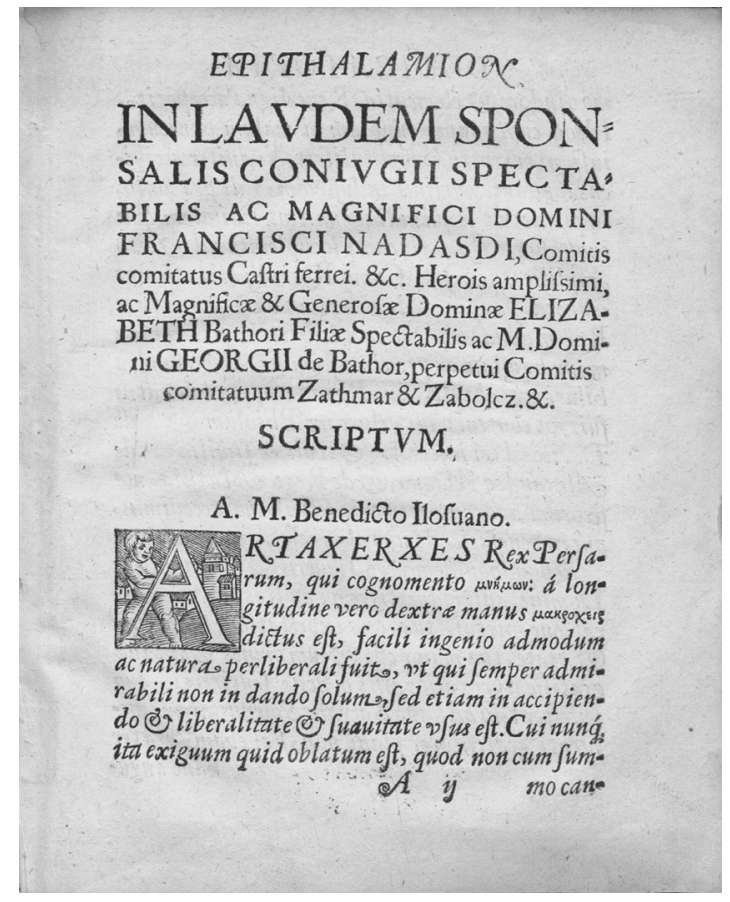

Il. 2. Dedykacja Benedikta Ilošvaia

Druk informował o wydarzeniu, które miało nastąpić w kręgu dwu ważnych rodów węgierskich. Typowe wówczas było, że w drukach, których bohaterkami były kobiety, wymieniano tylko ich imię, dodając informację o ojcu - w oma-

10 A. Szabó, op. cit., s. 96. 
wianym tutaj druku Elżbieta prezentowana jest jako córka Juraja Bátorego. Przez kilka wieków terminy ślubu i wesela ustalali rodzice nowożeńców. Także w wypadku tego druku inicjatorką była matka przyszłego oblubieńca: to ona wybrała kaznodzieję, aby węgierscy przedstawiciele wyższych warstw społecznych mogli dowiedzieć się o planowanym związku dwu ważnych rodów. Jak już wspomniano, ślub odbył się 8 maja 1575 roku we Vranowie nad Topl'ou, gdy pan młody miał 20 lat, a jego oblubienica Elżbieta Batory - 15 lat. Kto udzielał ślubu, nie wiadomo; nie był to oczywiście Ilošvai, który od 1573 roku przebywał na stałe w Alba Julia.

\section{EPITALAMIUM JAKO RODZAJ UTWORU OKOLICZNOŚCIOWEGO}

Epitalamia znane były już w starożytnej Grecji jako pieśni weselne, śpiewane przez chór dziewcząt i chłopców przy łożu weselnym. W Rzymie pieśni te, śpiewane wyłącznie przez młode panny, zawierały życzenia szczęśliwej przyszłości i płodności dla nowożeńców. W średniowieczu epitalamia straciły charakter pieśni chóralnej, a w ich treści pojawiły się wpływy chrześcijaństwa i chrześcijańska symbolika. Małżeństwo prezentowano jako uświęcony związek łączący dwie dusze. Teksty zawierały pochwały czystości przedmałżeńskiej oraz wyrazy czci dla Maryi. Dużą popularność tej formy literackiej przyniosły czasy renesansu, najpierw we Włoszech XIV-XV wieku, a później także w innych krajach europejskich. Epitalamia jako rodzaj poezji pochwalnej, panegirycznej doskonale nadawały się do głoszenia świetności władców, a z czasem również arystokracji, szlachty, a nawet bogatego mieszczaństwa. Innym ich celem była chęć uświetniania zaślubin, nadawania im jak największego przepychu. $\mathrm{W}$ dobie renesansu epitalamia stały się ważnym elementem rytuału weselnego, przybierały też różne formy gatunkowe (utwory liryczne, ody, panegiryki, sielanki, elegie, utwory udramatyzowane). Autorzy epitalamiów - wśród ktorych spotykamy takie znajomitości, jak Ludovico Ariosto, Giambattista Marino czy Pierre de Ronsard na nowo sięgali po wzory antyczne i posługiwali się postaciami bogów greckich i rzymskich w celu opisu wyjątkowych cech nowożeńców, jak miało to miejsce w opisywanym druku. Chwalili dzielność i zasługi przodków nowożeńców, często sięgając po biblijne motywy, wyrażające piękno, moc i trwałość miłości na wzór Salomonowej Pieśni nad pieśniami ${ }^{11}$.

Epitalamia były w większości niewielkimi objętościowo drukami z krótkimi tekstami, a ich publikację zlecali najczęściej krewni i przyjaciele adresatów. Były

11 K. Mroczek, Epitalamium staropolskie. Między tradycją literacka a obrzędem weselnym, Wrocław 1989, s. 31-39; eadem, Epitalamium, [w:] Słownik literatury staropolskiej, red. T. Michałowska, Wrocław 2002, s. 219. 
wśród nich — jak w opisywanym przypadku — wiersze gratulacyjne z okazji zaślubin, szczególnie osób wybitnych i wysoko postawionych w hierarchii społecznej. Dla drukarza oznaczały pewny dochód, gdyż nie musiał się obawiać strat trud typografa inicjowali i płacili zań, niekiedy z góry, członkowie rodziny lub przyjaciele nowożeńców.

\section{EPITHALAMION CONIUGII... BENEDIKTA ILOŠVAIA}

Epitalamium pióra Benedikta Ilošvaia reprezentuje obfity dział repertuaru wydawniczego dawnych wieków. Druk dzieli się na kilka części. Wstęp Dedicatoria przedstawia ideał władcy. Za wzór Ilošvai wybrał króla Persji Artaxerxesa I,

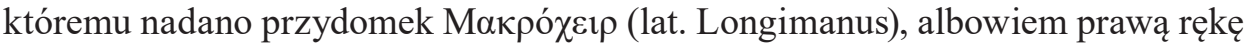
miał dłuższą od lewej. Jak wynika z tekstu, był to władca ludzki i szczodry. Autor przywołał także króla Macedonii Aleksandra Wielkiego i króla Węgier Macieja Korwina, którzy byli dla niego wzorami w czynieniu dobra. W zakończeniu dedykacji stwierdził, że chce tym skromnym dziełkiem odwdzięczyć się adresatce, a jednocześnie wyraził nadzieję, że przyczyni się ono do jego sławy.

W inwokacji poeta wzywa imienia Bożego i prosi Jezusa Chrystusa, aby jego serce napełnił twórczą siłą, liczy jednak zarazem na przychylność Pegaza. W kolejnej części opisuje konflikt militarny i walki, które zniszczyły naddunajskie miasto, a także spisek przeciw cesarzowi. Autor zamyślił bowiem swój utwór jako pochwałę bohaterstwa i waleczności mężów-bojowników pochodzących z obu rodów. Sam tekst epitalamium dotyczy nowożeńców tylko marginalnie.

Podobnie jak czynił to między innymi Ján Bocatius (Hungaridos libri poematum $V$ ), Ilošvai posłużył się typowymi antycznymi motywami, przywołując bogów (Hymen, Apollo, Mars, Amor), bohaterów (Achilles, Hektor, Bellerofont, Edyp), muzy, Parki, kameny, a nawet autorów - Owidiusza i Wergilego, których traktował jako swych niedościgłych literackich mistrzów. Świat antyku przeplatał się z wydarzeniami ze Starego Testamentu i chrześcijańską wizją małżeństwa. Choć trudno dziś trafnie ocenić artystyczną wartość i poetycką zręczność autora, należy uznać, że zachował wszystkie cechy typowe dla tego rodzaju literackiego. Będąc autorem chrześcijańskim, wykazał się znajomością zarówno historii Węgier, jak i mitologii oraz greckiej i rzymskiej literatury. W interesujący sposób splótł motywy antyczne i chrześcijańskie. Wzorem innych dzieł tego rodzaju Ilošvai swoje epitalamium zakończył zawierającym życzenia dystychem Votum eiusdem ${ }^{12}$.

12 K. Mroczek, Epitalamium staropolskie..., s. 126. 


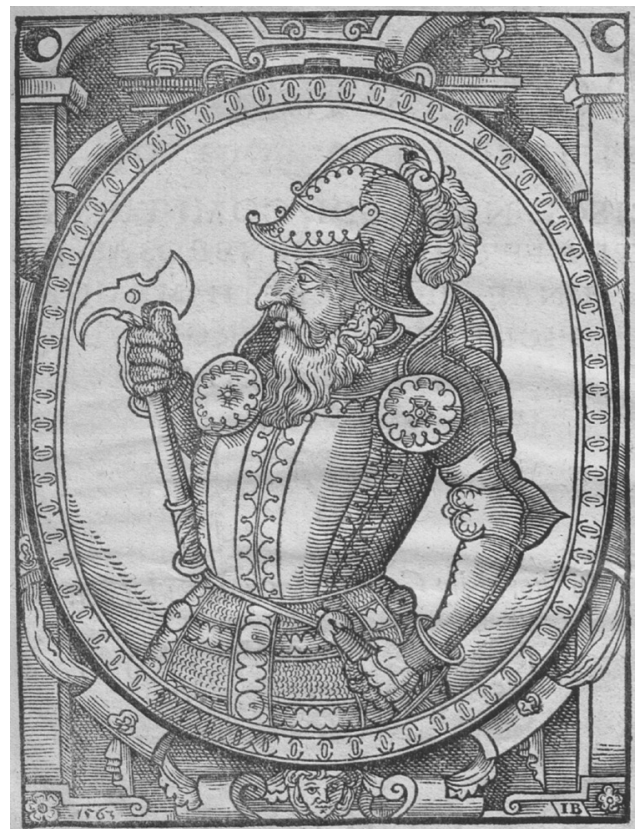

Il. 3. Popiersie rycearza, sygnowane I.B. 1563

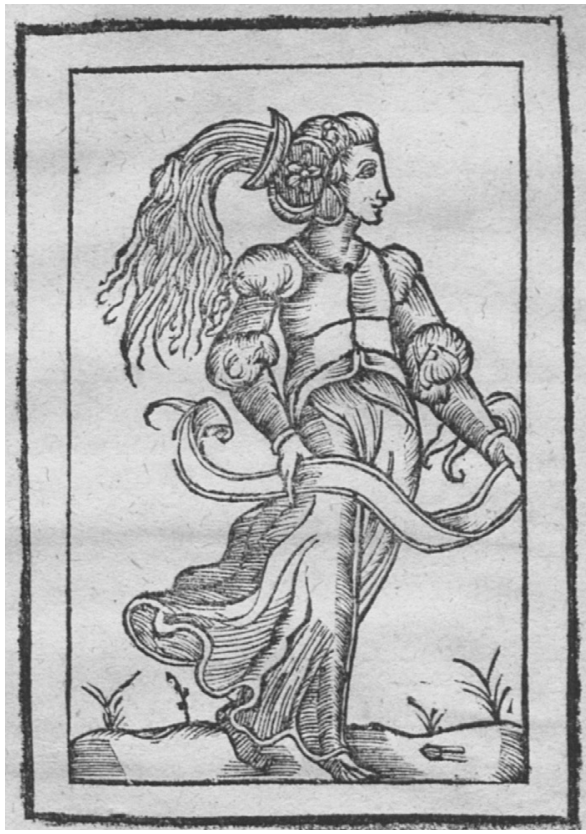

I1. 4. Postać dziewczęca

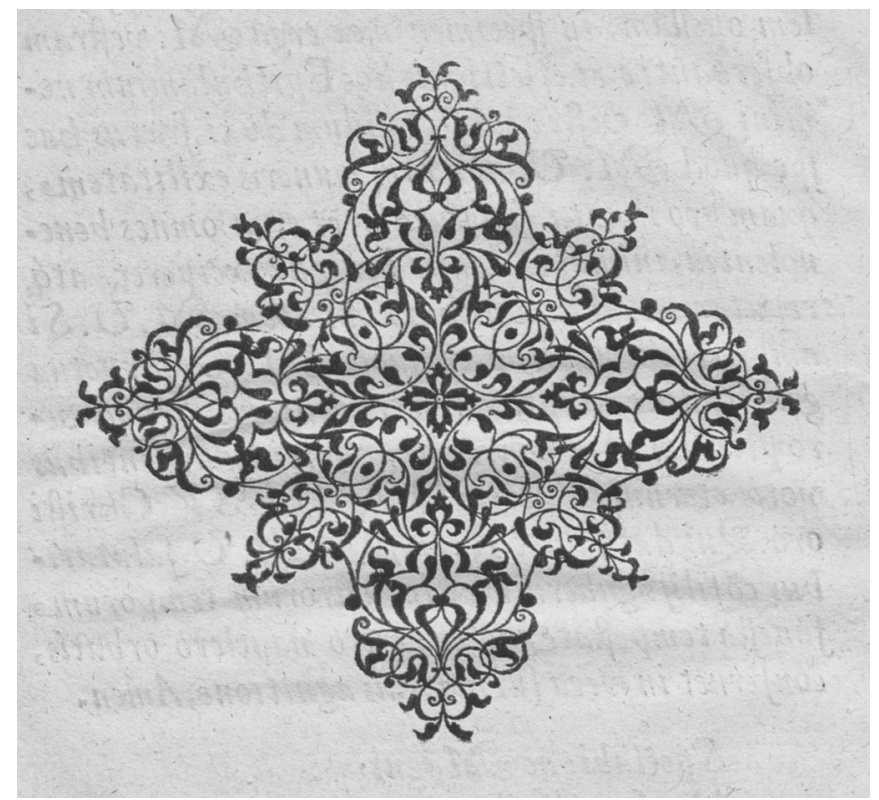

Il. 5. Winieta Mateusza Sibeneichera 


\section{KRAKÓW MIEJSCEM DRUKU EPITALAMIUM}

W XVI wieku Kraków był największym i najważniejszym ośrodkiem polskiego drukarstwa. W I połowie XVI wieku najaktywniejszymi drukarzami byli tutaj Jan Haller, Hieronim Wietor i Florian Ungler, w II połowie - Mikołaj Szarffenberg, Mateusz Siebeneicher i Jan Januszowski. Około 1580 roku działało tu osiem oficyn, których produkcja pod koniec XVI wieku dwukrotnie przewyższała produkcję wszyskich drukarń w reszcie Rzeczypospolitej. Wobec nieistnienia stałych drukarń na Węgrzech krakowskie oficyny często drukowały także zamówienia pochodzące od południowego sąsiada Rzeczypospolitej. Początek tym kontaktom w I połowie XVI wieku dał najprawdopodobniej księgarz krakowski Marcin Siebeneicher (zmarł w 1543 roku), który założył w Preszowie filię swojej firmy, zakupioną po jego śmierci przez jego współpracownika Marcina Guttlera. Wiadomo także, że pierwszy drukarz działający w Bardiowie (słow. Bardejov) od około 1577-1578 roku — David Gutgesel — po nauce drukarskiego rzemiosła w Wiedniu od 1570 roku pracował we Wrocławiu u Kryspina Scharffenberga, krewnego Szarffenbergów działających w Krakowie ${ }^{13}$. W II połowie XVI wieku współpracę z Węgrami kontynuował syn i następca Marcina Siebeneichera, Mateusz Siebeneicher (zmarł w 1582 roku), blisko spokrewniony z Szarffenbergami. W latach 1557-1582 w jego oficynie ukazały się łącznie 194 pozycje (104 w języku polskim, $90 \mathrm{w}$ łacińskim), w tym dzieła autorów węgierskich lub związanych z Węgrami. Jednym z nich była w 1567 roku Chronologia de regibus Hungaricis prius nunquam edita Abrahama Bakschaya — warto podkreślić, że dołączone tam epicedium adresowane było do wojewody sieradzkiego Olbrachta Łaskiego polskiego i węgierskiego magnata, który był przez pewien czas panem zamku w Kežmarku na Słowacji ${ }^{14}$.

Inicjatywa wydania epitalamium w Krakowie w oficynie Siebeneichera nie była więc dziełem przypadku, chociaż nie wiadomo, czy wyszła ona od kaznodziei - Ilošvaia, czy od członków rodzin nowożeńców. W tym czasie na Węgrzech nie było bowiem żadnej drukarni, która mogłaby wydać taką publikację.

\section{ILUSTRACJE JÖRGA BRÜCKNERA W EPITALAMIUM}

Autorkom udało się zidentyfikować twórcę artystycznych drzeworytów zamieszczonych w opisywanym druku. W książce występują — oprócz winiet orna-

${ }^{13}$ Drukarze dawnej Polski od XV do XVIII wieku. Praca zbiorowa, T. 1. Małopolska, cz. 1. Wiek XV-XVI, pod red. A. Kaweckiej-Gryczowej, Wrocław 1983, s. 201; Encyklopedia wiedzy o ksiażce, Wrocław 1971, szp. 2263.

${ }^{14}$ Drukarze dawnej Polski..., s. 209. 
mentalnych, fryzu i ozdobnych inicjałów - dwa drzeworyty, z których pierwszy jest sygnowany monogramem I.B. z datą 1563. Pierwszy przedstawia popiersie mężczyzny — wojownika w rycerskiej zbroi, drugi — postać młodej dziewczyny $\mathrm{z}$ banderolą. Bez wątpienia są to ilustracje przedstawiające anonimowe osoby, a nie ryciny ukazujące prawdziwe wizerunki Nádašdyego i Batory, na co zresztą wskazuje data sporządzenia pierwszego $\mathrm{z}$ drzeworytów). Z pewnością drukarz wykorzystał po prostu drzeworyt, który miał do dyspozycji 15 .

Twórcą pierwszego drzeworytu był najprawdopodobniej Jörg (Georg, Jerzy) Brückner, rysownik i drzeworytnik, który działał w latach 1560-1570 we Wrocławiu, a następnie w Krakowie, gdzie zmarł w 1594 roku na skutek ran odniesionych w nieszczęśliwym wypadku ${ }^{16}$. Wprawdzie jego poświadczona dokumentacyjnie działalność w Krakowie związana jest z oficyną Łazarzową Jana Januszowskiego $^{17}$, wiele przemawia jednak za tym, że jeszcze w czasie pobytu we Wrocławiu współpracował z oficynami krakowskimi. Jego dorobek artystyczny jest jednak dyskusyjny ${ }^{18}$, nie sposób też z całą pewnością utożsamiać go z twórcą sygnującym swoje dzieła monogramem I.B. Wątpił w to już Edward Rastawiecki ${ }^{19}$, a z współczesnych nam badaczy Ewa Chojecka ${ }^{20}$. Sprawa ta wymaga więc dalszych badań, także pod kątem stylu artystycznego przypisywanych mu drzeworytów. Nie można też wykluczyć, że Jörg (Georg, Jerzy) Brückner i Grzegorz Brückner to różne

15 Może sprawą zainteresują się polscy badacze i sprawdzą, czy był on już gdzieś wykorzystany wcześniej przed rokiem druku opisywanego tu epitalamium?

16 W literaturze wzmiankowany także pod imieniem Grzegorz. Zob. G.K. Nagler, Monogrammisten, T. 3, München 1921, s. 815; E. Rastawiecki, Stownik rytowników polskich tudzież obcych w Polsce osiadtych lub czasowo w niej pracujacych, Poznań 1886, s. 19-20; E. Chojecka, Brückner Grzegorz, [w:] Słownik artystów polskich i obcych w Polsce działających, T. 1. Malarze, rzeźbiarze, graficy, Wrocław 1971, s. 250.

17 Drukarze dawnej Polski..., s. 88-89 (jako Grzegorz Brückner); B. Miodońska, Władca i państwo w drzeworycie książkowym XVI w., [w:] Renesans. Sztuka i ideologia, red. T.S. Jaroszewski, Warszawa 1976, s. 86-90 (jako Jerzy Brückner). Jego kilka drzeworytów (sygnowanych G.B.) ozdobiło wydane w 1594 roku w Drukarni Łazarzowej Statuta i metrykę przywilejów koronnych Stanisława Sarnickiego. Według Miodońskiej istnieją jednak podstawy ,do uznania Georga (Jörga) Brücknera za wykonawcę całości wyposażenia artystycznego Statutów Sarnickiego", ze względu na jednolity charakter stylistyczny tego wyposażenia.

18 Nie wymienia go Małgorzata A. Quinkstein (Unikatowy album drzeworytów. Brudnopis Józefa Muczkowskiego, „Pamiętnik Biblioteki Kórnickiej” 2005, nr 27, s. 103-107), która szczegółowo przedstawiła ten zbiór zachowanych rycin i jego pochodzenie.

19 Według niego przypisanie przez Naglera Brücknerowi rysunków w Kronice Bielskiego pod znakiem IB ,zdaje się błędne, bo Brückner sprowadzony był później do Krakowa przez Januszowskiego. Z cyfrą zaś tą I.B. znane są liczne dawniejsze drzeworyty krakowskie, które do innego drzeworytnika muszą należeć" - idem, op. cit.

20 Stwierdza ona o Grzegorzu Brücknerze: „Identyfikowany przez Naglera ze znanym z lat sześćdziesiątych XVI w. drzeworytnikiem monogramistą IB, co wydaje się jednak mało prawdopodobne" - E. Chojecka, op. cit. 
osoby, za czym przemawiałoby używanie przez nie dwóch różnych monogramów: I.B. (1563 rok) i G.B. (1594 rok). W każdym razie do jego prac można zaliczyć kilka drzeworytów do polskiej kroniki Marcina Bielskiego, portrety cara Iwana Groźnego, polskiego króla Zygmunta I Starego z 1563 roku (a więc sporządzony w tym samym roku co wizerunek wojownika w omawianym tutaj druku) oraz przedstawienia postaci Adama i Ewy ${ }^{21}$.

\section{KRAKOWSKI DRUK EPITHALAMION CONIUGII... Z 1571 ROKU WE WSPÓŁCZESNYCH ZBIORACH BIBLIOTECZNYCH}

Należy przypuszczać, że druki takie gromadzono przede wszystkim w księgozbiorach szlacheckich. Opisywany tu egzemplarz Epithalamion coniugii... w XIX wieku znalazł się w zbiorach znakomitego polskiego kolekcjonera Zygmunta Czarneckiego (1823-1908) w Rusku w Wielkopolsce. Na zlecenie Czarneckiego został on oprawiony w półpergamin i opatrzony jego pozłacanym superekslibrisem. Wraz z jego liczącą ponad 7 tysięcy woluminów kolekcją starych druków został zakupiony przez Bibliotekę Fundacji Wiktora hr. Baworowskiego we Lwowie i wraz z całością jej zbiorów trafił w 1940 roku do Biblioteki Zakładu Narodowego im. Ossolińskich we Lwowie. Następnie wraz z częścią zbiorów Biblioteki ZNiO w 1946 roku znalazł się we Wrocławiu ${ }^{22}$. Druk ten rejestruje Bibliografia polska Karola Estreichera (T. 18, Kraków 1870, s. 560) oraz Katalog starych druków Biblioteki Zakładu Narodowego im. Ossolińskich. Polonica wieku XVI w opracowaniu Marii Bohonos (Wrocław 1965, poz. 1182), a jedyny egzemplarz z dedykacją autorską zachował się w skonfiskowanej przez władze habsburskie bibliotece wnuka Františka Nádašdyego, Františka III, straconego w 1671 roku w Wiedniu ${ }^{23}$. Druk ten dotychczas nie został odnotowany w zbiorach żadnej innej biblioteki.

${ }^{21}$ Zob. m.in. D. Śnieżko, Kronika wszystkiego świata Marcina Bielskiego. Pogranicze dyskursów, Szczecin 2004, s. 45, 47. Dwie z wymienionych rycin (portret Iwana Groźnego oraz Adam i Ewa) zamieszczone są w pracy Zbiór odcisków drzeworytów w różnych dziełach polskich XVI i XVII wieku odbitych a teraz w Bibliotece Uniwersytetu Jagiellońskiego zachowanych, Cracoviae 1849, il. 280, 732 .

22 Można dodać, że kolekcja Biblioteki Baworowskich została w latach 1944-1946 rozproszona i stare druki z niej pochodzące znajduja się dziś w trzech miastach — oprócz Wrocławia także w Warszawie (w Bibliotece Narodowej) oraz w Ukrainie we Lwowie (w Narodowej Bibliotece Ukrainy im. W. Stefanyka).

23 O tym egzemplarzu wzmianowuje N. Viskolcz w swojej pracy A mecenatúra színterei a föuri udvarban Nádasdy Ferenc könyvtára (Szeged-Budapest 2013, s. 607, s. 720-721). Wraz z innymi książkami należącymi do Nádašdyego miał się on dostać do cesarskiej biblioteki nadwornej w Wiedniu (obecnie Österreichische Nationalbibliothek). 


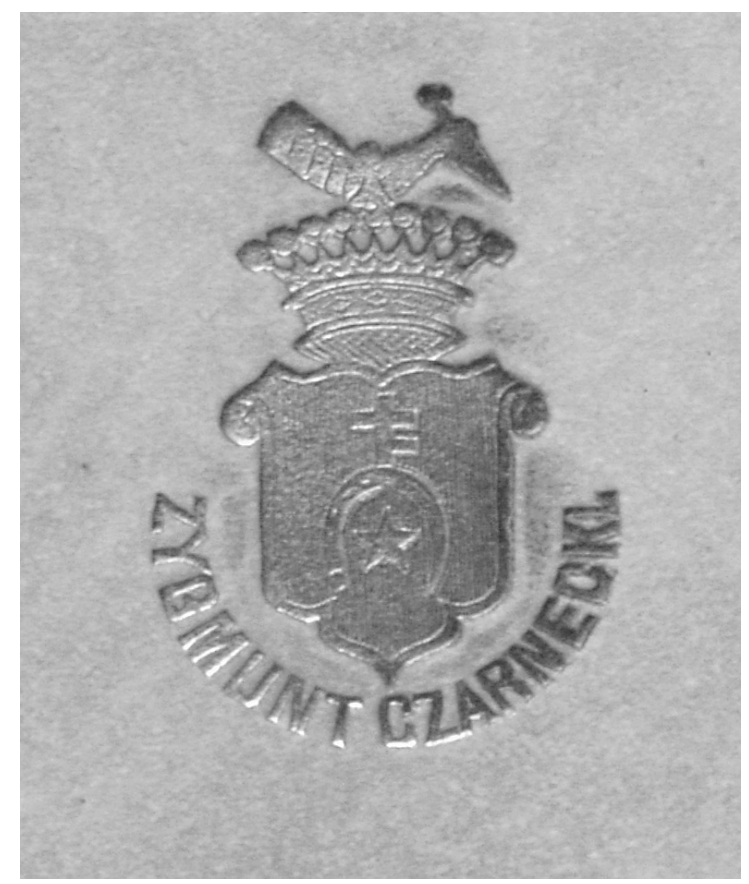

Il. 6. Superekslibris Zygmunta Czarneckiego

\section{ZAKOŃCZENIE}

Opisany w niniejszym artykule druk Epithalamion coniugii... przede wszystkim przynosił informację o nadchodzącym wydarzeniu, do którego wówczas niewatpliwie przywiązywano duże znaczenie, przygotowywane małżeństwo mogło bowiem zmienić układ sił na Węgrzech. Autor zawartego w druku utworu literackiego, wykształcony i zorientowany w sytuacji europejskiej, oferował czytelnikowi poetycki obraz przodków nowożeńców. To ich dzielność i pobożność w jakimś stopniu miała być gwarancją szczęśliwego małżeństwa Františka i Elżbiety. Drukowane epitalamium jest przykładem ówczesnej formy prezentacji przyszłego wydarzenia, lecz także gustów epoki, które znalazły wyraz w wykorzystanych ilustracjach, choć odzwierciedlały w istocie nie podobizny nowożeńców, ale zasób materiału typograficznego, jakim dysponował drukarz.

Upodobanie do publikowania epitalamiów przetrwało trzy stulecia; ich druk zlecali już od XVI wieku mieszczanie, a także urzędnicy różnych szczebli, przedstawiciele wykształconej inteligencji i kleru. Na terenie Słowacji epitalamia przez kilka wieków były stałą częścią repertuaru drukarń. 


\section{BIBLIOGRAFIA}

Bandtkie J.S., Historya drukarń krakowskich od zaprowadzenia druków do tego miasta aż do czasów naszych, Kraków 1815, s. 245-352.

Bartholomaeides I.L., Memoriae Vngarorum qui in alma condam vniversitate Vitebergensi a tribus proxime concludendis seculis studia in ludis patriis coepta confirmarunt, Pesthini 1817, s. 35.

Bernhard J.A., Konsolidierung des reformierten Bekenntnisses im Reich der Stephanskrone, Göttingen 2015, s. 336-337, 348, 371.

Biografickýlexikón Slovenska, T. 1. A-B, Slovenska Narodna Knižnica — Národný bibliografický ústav, Martin 2002, s. 269-270.

Biografický lexikón Slovenska, T. 6. M-N, Slovenska Narodna Knižnica — Národný bibliografický ústav, Martin 2017, s. 648.

Bohonos M., Katalog starych druków Biblioteki Zakładu Narodowego im. Ossolińskich. Polonica wieku XVI, Wrocław 1965, s. pozn. 1182.

Chojecka E., Brückner Grzegorz, [w:] Stownik artystów polskich i obcych w Polsce działajacych, T. 1. Malarze, rzeźbiarze, graficy, Wrocław 1971.

Csepregi Z., Evangélikus lelkések Magyarországon 1522-1610, medit.luteran.hu/files/ELEM/1_1522 1610 A L.pdf [dostęp: 5.06.2018].

Čaplovič J., Bibliografia tlačí vydaných na Slovensku do roku 1700, T. 2, Martin 1984, č. 1405, č. 1633.

Dmitrieva M., Lambrecht K., Krakau, Prag und Wien: Funktionen von Metropolen im frühmodernem Staat. (Forschungen zu Geschiche und Kultur des östlichen Mitteleuropa (Fgkom), T. 10, Stuttgart 2001.

Drukarze dawnej Polski od XV do XVIII wieku. Praca zbiorowa, T. 1. Małopolska, cz. 1. Wiek XVXVI, pod red. A. Kaweckiej-Gryczowej, Wrocław 1983, s. 209.

Dvořák P., Krvavá grófka. Alžbeta Bátoryová, fakty a výmysly, Budmerice 1999.

Encyklopedia wiedzy o ksiażce, Wrocław 1971.

Enyedi G., Káldos J., Historia elegantissima, Balassi, Budapest 1994, OCLC 895184770.

Fabiny T., Egyháztörtönet - Monografiak, Budapest 1984, s. 217-218, 226, 229, 237-238, 348.

Fabó A., Monumenta Evangelicorum Aug. Conf, [w:] Hungaria historica II, Pest 1863.

Farin M., Heroine des Grauens. Elisabeth Báthory, München 2003.

Gwioździk J., Druki z 1. połowy XVI. w. z kolekcji Zygmunta Czarneckiego w zbiorach lwowskich. „Bibliotheca Nostra. Śląski Kwartalnik Naukowy” 2014, nr 4 (38), s. 70-83, https://www. nu.sbc.org.pl [dostęp: 2.07.2018].

Hammer W., Die Melanchton-Forschung im Wandel der Jahrhunderte (,Quellen und Forschungen zur Reformationsgeschichten” 3), Mohn, Gütersloh 1981, s. 336, pozn. 309.

Kalsruher Virtueller Katalog, http://www.karlsruhe.de [dostep: 27.05.2018].

Kerul'ová M., Ján Bocatius a jeho dielo Hungaridos libri poematum V., [w:] Poeta laureatus Ioannes Bocatius (1569-1621). Zbornik z celoslovenskej konferencie, ktorá sa konala $v$ dňoch 29.-30. septembra 2009 v Košiciach pri príležitosti 440. výročia narodenia a 410. výročia príchodu Jána Bocatia do Košíc, Košíce 2009, s. 45-68.

Kis3g, https://www.kis3g.sk/ [dostęp: 24.05.2018].

Klein J.S., Nachrichten von den Lebensumständen und Schrifften der evangelischen Predigern in Ungarn, T. 2, Leipzig-Ofen 1789, s. 460, pozn. 340.

Majtán M., Názvy obcí Slovenskej republiky. (Vývoj v r. 1773-1997), Bratislava 1998, s. 332, č. 2695. McNally R., Dracula Was a Woman. In Search of the Blood Countess of Transylvania, New York 1983. Metropolen und Kulturtransfer im 15./16. Jahrhundert. Prag - Krakau - Danzig - Wien, red. A. Langer, G. Michels, Stuttgart 2001.

Miodońska B., Wtadca i państwo w drzeworycie ksiązkowym XVI w., [w:] Renesans. Sztuka i ideologia, red. T.S. Jaroszewski, Warszawa 1976, s. 86-90.

ROCZNIKI BIBLIOTECZNE

ROK LXIII, 2019

(C) for this edition by CNS 
Mroczek K., Epitalamium staropolskie. Między tradycją literacka a obrzędem weselnym („Studia Staropolskie" 55), Wrocław 1989, s. 31-39.

Mroczek K., Epitalamium, [w:] Stownik literatury staropolskiej, red. T. Michałowska, Wrocław 2002.

Muczkowski J., Zbiór drzeworytów w Bibliotece Uniwersytetu Jagiellońskiego zachowanych, Kraków 1849.

Nagler G.K., Monogrammisten, T. 3, München 1921, s. 815.

Petrík B., Evanjelická encyklopédia Slovenska, oprac. P. Rybár, Bratislava 2001, s. 174.

Parandowski J., Mytológia, Tatran, Bratislava 1980.

Penrose V., The Bloody Countess. The Crimes of Elizabeth Bathory, London 1996.

Rastawiecki E., Stownik rytowników polskich tudzież obcych w Polsce osiadtych lub czasowo w niej pracujacych, Poznań 1886, s. 19-20.

Quinkenstein M.A., Unikatowy album drzeworytów „Brudnopis Józefa Muczkowskiego”, „Pamiętnik Biblioteki Kórnickiej” 2005, nr 27, s. 103-107, bazhum.muzhp.pl/media//files/Pamietnik_ Biblioteki_Kornickiej [dostęp: 28.06.2018].

Slovenský biografický slovnik, T. 4, Martin 1990, s. 254.

Slovnik antickej kultúry, Svoboda, Praha 1974, s. 189, 276.

Soltész E., Velenczei K., Salgó A.W., Az Országos Széchényi könyvtár 16. századi nyomtatványainak katalógus, T. 2. F-O, Budapest 1990.

Szabó A., Coetus Ungaricus a Wittebergi Magyar diáktarsaság 1555-1613, „Reformatus Szemle” 110,2017, nr 5, s. 524-525.

Szabó A., Ilosvai Benedek, Gyulafehérvári plébános - Eruditio, virtus et constantia, „Irodalomtörténeti közlömények" 115, 2011, nr 2, s. 627-633.

Śnieżko D., Kronika wszystkiego świata Marcina Bielskiego. Pogranicze dyskursów, Szczecin 2004.

Thorne T., Countess Dracula. The Life and Times of Elisabeth Bathory, the Blood Countess, London 1997.

Valach J., Staré tlačiarne a tlačiari na Slovensku, Martin 1987, s. 92.

Viskolcz N., A mecenatúra szinterei a föúri udvarban Nádasdy Ferenc könyvtára, red. I. Monok, Szeged-Budapest 2013, s. 675, 720-721

Zbiór odcisków drzeworytów w różnych dziełach polskich XVI i XVII wieku odbitych a teraz w Bibliotece Uniwersytetu Jagiellońskiego zachowanych, Cracoviae 1849.

\section{VLASTA OKOLIČÁNYOVÁ \\ KATARÍNA DEVEROVÁ \\ GABRIELA ŽIBRITOVÁ}

\section{THE BETROTHAL OF FRANTIŠEK NÁDAŠDY AND ELIZABETH BÁTHORY AS A SOCIAL EVENT AND LITERARY FACT IN THE SIXTEENTH CENTURY}

\section{Summary}

The article deals with an occasional publication by Benedikt Ilošvai (Benedictus Ilosvanus), printed in 1571 in Mateusz Siebeiecher's printing house in Kraków to mark the betrothal of Elizabeth Báthory to František Nádašdy. The authors discuss its historical context associated with the figures of the two spouses, circumstances of the publication, its content as well as editorial layout (with illustrations probably by Jörg Brückner).

KEY WORDS: František Nádašdy, Elizabeth Báthory, Benedikt Ilošvai, sixteenth-century printing in Kraków, epithalamium

\section{ROCZNIKI BIBLIOTECZNE}

ROK LXIII, 2019

(C) for this edition by CNS 